\title{
NIKAH BEDA AGAMA DALAM KAJIAN HUKUM ISLAM DAN TATANAN HUKUM NASIONAL
}

\author{
Muhammad Ilham \\ ilham@stainkepri.ac.id \\ STAIN Sultan Abdurrahman Kepulauan Riau
}

\begin{abstract}
Legitimate marriage is a dream for couples and harmony in family life, so that in Islam always depends on the ultimate goal Marriage is to get sakinah, mawaddah and warohmah. With this aim, sometimes it is wrong to place the rules of marriage only, one of them agreeing on a harmonious family but forgetting to look at the couple's religious side. The phenomenon of interfaith marriages often occurs not only in different countries but also in Indonesia, a lot of this is done. This study aims to look at the phenomenon of interfaith marriage in a qualitative form so that the ultimate goal can be developed with special concepts to be given at specific conclusions with various updates. Interfaith marriages often occur in Indonesian society, in marriage law No. 1 of 1974 concerning marriage clearly has a ban. Also in the Compilation of Islamic Law in Article 40 paragraph (c) and Article 44, too. The same can also be seen in the MUI Fatwa. Nevertheless, there are also some opinions of scholars who allow marriages of different religions from Muslim men and women experts of the book. In response, it is fitting to look at the social conditions of people in Indonesia who uphold religious norms, so that depending on the committee will be corrected on the understanding of specific ideas in matters of religion.
\end{abstract}

Keywords : Marriage, Religion, Islamic Law

\section{A. Pendahuluan}

Nikah sering diidentikkan oleh masyarakat Indonesia sebagai suatu bentuk proses saling memiliki dan menjaga antara laki-laki dan perempuan dengan jalan yang sah baik sah secara agama maupun sah dalam undang-undang nasional, sehingga tercapainya kehidupan suatu keluarga untuk membentuk rumah tangga baru. Bentukan ini tentunya melalui proses dan persyaratan yang harus ditunaikan bagi calon yang ingin melaksanakan pernikahan. Sehingga dengan memenuhi syarat tersebut maka terhindar dari hal-hal yang membatalkan pernikahan.

Banyak hikmah yang didapatkan dengan melaksanakan pernikahan, mulai dari membangun rumah tangga baru, sampai kepada merawat anak. Kesemua itu menjadi tantangan lahir dan batin tersendiri bagi yang telah menikah, antara suka dan duka yang diterima oleh pasangan tersebut. Oleh karena itu, semua manusia yang sehat secara akal dan pikirannya tentu ingin membina rumah tangga bersama pasangan yang disukainya. 
Dalam upaya memilih pasangan, tentu ini menjadi hak bagi yang ingin melaksanakan pernikahan, sebab pernikahan ditujukan untuk kelangsungan hidup secara bersama secara aman, bahagia dan tenteram dalam rumah tangga. Meskipun seringkali kita mendengar ada istilah "dijodohkan" oleh orang tua, namun hal itu tetap kembali kepada pribadi masing-masing yang ingin menikah, apakah dia mau dengan perjodohan tersebut? Apakah bisa membina rumah tangga secara bahagia dari perjodohan tersebut? Jawabannya kembali kepada diri masing-masing. Sehingga tidak melanggar hak-hak individu dalam membina rumah tangga.

Pada sisi religius, bahwa dalam hal mencari pasangan tentu dihadapkan pada aturan main pada ajaran Agama masing-masing. Kesemuanya mengatur mulai dari mencari pasangan sampai kepada melaksanakan nikah. Misalnya pada Islam, salah satu inti ajaran islam dalam mencari pasangan adalah berdasarkan agamanya. Hal ini tentu mendapatkan perhatian lebih bahwa se-Agama adalah tujuan utama dalam mencari pasangan untuk berkeluarga. Namun demikian, terkait dengan menikah dengan pasangan yang berbeda agama, para ulama memberikan perbedaan pendapat tentang keboleh hal terseebut.

Dalam hal menikah dengan pasangan yang berbeda agama, Islam memiliki prasyarat tersendiri, sehingga ketentuan tersebut menjadi pokok ajaran agama penting bagi individu dalam memilih pasangan untuk melangsungkan pernikahan.

Seringkali terjebak pada pemahaman ayat al-Quran yang hanya secara gamblang saja dari persoalan pernikahan beda agama, padahal sebenarnya butuh pemahaman dan ilmu yang mendalam tentang kebolehan tersebut serta mengetahui asbab yang terjadi pada ayat yang diturunan tersebut.

Fenomena yang terjadi pada artis - sebagai publik figur - yang beberapa kita saksikan bahwa mereka melakukan hal tersebut atas dasar saling suka serta dianggap bukan lagi sebagai suatu yang tabu bagi masyarakat indonesia. ${ }^{1}$ Kejadian seperti ini bagi kalangan akademisi menarik dikaji serta dipelajari seksama, sebab hal ini selalu menjadi perhatian dan pandangan masyarakat khususnya masyarakat pedesaan yang tingkat reliugius dan kepercayaan pada agama cukup tinggi. untuk menjawab hal tersebut butuh pemahaman yang cukup serius dan mendalam, terlebih lagi dalam hal kaitannya dengan prinsip Islam.

Persoalan yang timbul akibat dari kurangnya rasa ingin memahami secara komprehensif terhadap al-Qur'an dan Sunnah sebagai sumber hukum Islam menjadi pondasi utama dalam penetapan hukum. Oleh karena itu berbagai upaya yang dilakukan oleh ulama klasik dalam memahami sumber tersebut dengan menetapkan berdasarkan metodologi tertentu khususnya pada hal-hal yang terkait dengan ibadah dan muamalah.

Kajian-kajian akademis menuntut kita untuk terus dapat memahami tentang persoalan-persoalan yang belakangan terjadi sesuai dengan kaidah-kaidah yang berlaku serta tetap mengedepankan sumber Hukum Islam termasuk pada hal nikah beda agama. Kajian ini diharapkan nantinya menjadi literasi bagi kalangan akademisi dan bagi masyarakat tentang nikah beda agama dalam persepektif fiqh kontemporer dan menegakkan kaidah-kaidah yang berlaku.

1 “5 Artis Yang Menikah Beda Agama," kumparan, t.t., diakses 8 Maret 2020. 


\section{B. Metodologi Penelitian}

Pembahasan yang berhubungan dengan masalah yang telah dipaparkan sebelumnya tentunya harus mengetengahkan metodologi yang baik sehingga akan menghasilkan solusi dan kesimpulan yang tepat sesuai dengan tujuan penelitian. Sebagaimana diketahui bahwa guna dari penelitian merupakan alat untuk memperoleh suatu pengetahuan tentang hal-hal yang diyakini secara keilmuan itu benar melaui berbagai proses baik dalam bertanya maupun dalam hal menjawab. ${ }^{2}$

Mengenai pembahasan ini dapat kita perhatikan bahwa metodologi yang tepat untuk dikembangkan adalah dengan pendekatan kualitatif, sehingga sesuai dengan prinsipnya ingin memberikan, menerangkan dan mendeskripsikan secara lugas dan kritis sehingga didapati makna dalam konteks yang sebenarnya. ${ }^{3}$

Upaya untuk memahami tentang nikah beda agama ini, perlu di Maping secara jelas cakupan yang digunakan dalam penulisan ini, sehingga tampak arah yang ingin dicapai serta dapat mencakup gambaran tentang Nikah dalam hal berbeda keyakinan dalam persepektif Hukum Islam dan Kompilasi Hukum Islam. Sebagaimana diketahui bahwa nikah Beda agama dimaksudkan disini terdiri dari 2 kategori yakni: 1) kategori pernikahan antara seorang laki-laki dengan berkeyakina muslim biasa dengan perempuan yang berkeyakinan Non muslim biasa, dan 2) kategori pernikahan antara laki-laki berkeyakinan muslim dari kalangan biasa dengan perempuan berkeyakina Non muslim dari kalangan Ahli Kitab.

Akhir dari tulisan ini penulis berupaya untuk menganalis secara Induktif yang didasari dari hal-hal khusus sehingga menghasilkan suatu kesimpulan umum. sehingga arah dalam pembahasan penelitian nikah beda Agama ini secara literatur akademik dapat menjadi bahasan menarik untuk dikaji.

\section{Pengertian Nikah}

Sebelum memberikan defenisi tentang nikah, perlu diluruskan bahwa kata "nikah" sering disama artikan dengan "kawin" dalam istilah masyarakat umum di Indonesia, meskipun dalam literatur kamus bahasa indonesia kedua istilah tersebut memiliki makna tersendiri akan tetapi tetap pada tujuan yang sama. Oleh karena itu penulis berupa membahasakan dalam tulisan ini pada kedua istilah tersebut.

Penggunaan Istilah Perkawinan (pernikahan) dalam kajian literatur ilmu fiqh merupakan kata dari bahasa arab yang dibentuk dari kata, yaitu "nikah" dan "zawaj", pada makna dari kata tersebut sering dipergunakan dalam keseharian oleh masyarakat arab dan juga literaturnya banyak kita temukan pada Al-Qur'an dan Sunnah Nabi. ${ }^{4}$

Pada literatur lain dijelaskan bahwa Nikah secara bahasa dibentuk dari istilah kNeã dan yang berarti berkumpul ${ }^{5}$. Kemudian disebutkan pula bahwa nikah

\footnotetext{
${ }^{2}$ W. Gulo, Metodologi Penelitian (Jakarta: Gramedia Widiasarana Indonesia, 2002), Hal. 10

3 A. Muri Yusuf, Metode Penelitian: Kuantitatif, Kualitatif, dan Penelitian Gabungan (Jakarta: Kencana, 2015). Hal. 338

${ }^{4}$ Jamaluddin dan Nanda Amalia, Buku Ajar Hukum Perkawinan (Unimllal Press, 2016). Hal. 16

${ }^{5}$ Ahmad Atabik dan Khoridatul Mudhiiah, "Pernikahan dan Hikmahnya Perspektif Hukum Islam," YUDISIA: Jurnal Pemikiran Hukum Dan Hukum Islam 5, no. 2 (2016). Hal. 287
} 
bermakna "berkumpul menjadi satu"6. Jelas pada kedua makna secara bahasa diatas lebih mengetengahkan pada konsep berkumpul, tentunya makna ini jika diterjemahkan secara gamblang bahwa berkumpul disini dari terpisah menjadi satu dengan berkumpul.

Disamping secara bahasa, perlu juga kita meliat secara istilah tentang Nikah, hal ini dapat kita melihat dari berbagai pendapat yang dikemukakan. Berkaitan dengan tersebut diatas, maka ahli Ushul dan Ahli fiqh memberikan pendapat masing-masing tentang nikah, misalnya menurut pendapat ahli ushul berikut:

1. Dalam pengertian yang sesungguhnya bermakna setubuh. Jika dilihat secara secara majazi (metaphoric) ialah kesepakatan dalam bentuk akad sehingga terjadi hubungan kelamin yang dihalalkan antara seorang pria dengan seorang wanita yang sesuai dengan ketentuan Syariat. Pendapat ini dikemukakan oleh Ahli Ushul kalangan Hanafyah.

2. Sedangkan dari kalangan Syaf'iyah memberikan pengegasan bahwa nikah sebenarnya adalah suatu kesepakan yang dibentuk dengan akad yang antara pria dan wanita menjadi halal dalam berhubungan kelamin. Jika ditentukan dalam arti majas bahwa Nikah dimaknai dengan bersetubuh.

3. Pendapat lain dari Abu Qasim al-Zayyad, juga dari Imam Yahya, dan juga dari Ibnu Hazm serta sebagian ahli ushul dari sahabat Abu Hanifah memberikan argumen tentang nikah yakni memiliki kedua arti secara bersamaan, yakni bisa disebut sebagai akad dan juga bisa disebut dengan setubuh. ${ }^{7}$ berikut:

Sedangkan para ahli Fiqh memuat beberapa defenisi antara lain sebagai

1. Ulama Hanafyah berpendapat bahwa nikah adalah:

"Nikah merupakan suatu bentuk akad yang secara sengaja dilakukan dengan tujuan memperoleh ketenangan/kesenangan".

2. Ulama Syafi'iyah berpendapat bahwa nikah adalah:

"Nikah dimaknai dengan suatu bentuk akad yang mengandung makna untuk mendapatkan kebahagiaan/kesenangan (wathi") disertai lafadz nikah, kawin atau yang semakna dengan itu."

3. Hanabilah berpendapat bahwa:

"nikah dimaksudkan sebagai suatu bentuk akad yang menggunakan lafadz nikah (tazwij) agar menjadi sah secara hukum untuk mengambil manfaat dan kesenangan dengan wanita yang dinikahi."

Dari berbagai defenisi yang dikemukakan diatas, maka seharusnya kita dapat memahami bahwa tidak terdapat literasi yang berbeda yang berbeda secara maknawi kecuali terdapat pada redaksinya saja. Nikah pada intinya diterjemahka dengan bentuk akad yang agama telah mengaturnya dalam memberikan kesempatan bagi seorang pria dan seroang wanita untuk bisa mendapatkan serta berhubungan dalam bentuk menikmati faraj dan seluruh tubuh wanita itu dan juga dengan tujuan membentuk keluarga. ${ }^{8}$

${ }^{6}$ Zainuddin Ibnu Abdul Aziz Al Malibari, Fathul Muin Jilid 3, trans. oleh Abul Hiyadh, I (Surabaya: Al-Hidayah, 1993). Hal. 1

${ }^{7}$ Atabik dan Mudhiiah, "Pernikahan dan Hikmahnya Perspektif Hukum Islam." Hal. 287

${ }^{8}$ Atabik dan Mudhiiah. Hal. 288 
Sejalan dari konsep tersebut, bahwa sebagai negara yang menganut pancasila sebagai dasarnya juga telah menetapkan aturan main yang berkaitan dengan perkawinan/pernikahan, dapat kita temukan pada Undang-undang Nomor 1 Tahun 1974 tentang Perkawinan yang sekarang terjadi perubahan dengan Undang-undang Nomor 16 Tahun 2019 tentang Perkawinan. Meskipun demikian secara pengertian dasar dari UU Nomor 1 Tahun 1974 tentang perkawinan yang dalam perubahan tidak signifikan bentuk perubahanya, misalnya pada pasal 2 dijelaskan tentang perkawinan bahwa9:

"Perkawinan adalah ikatan lahir batin antara seorang pria dan seorang wanita sebagai suami istri dengan tujuan membentuk keluarga atau rumah tangga yang bahagia dan kekal berdasarkan Ketuhanan Yang Maha Esa.'”

Pada penjelasan lain dapat juga kita lihat dalam Instruksi Presiden berupa Kompilasi Hukum Islam (KHI) dikeluarkan tahun 1991 pada masa pemerintahan Presiden Soeharto yang memuat dengan tiga buku yakni perkawinan, kewarisan dan perwakafan. Pada buku perkawinan dijelaskan pada pasal 2 dijelaskan bahwa ${ }^{10}$ :

"Perkawinan menurut hukun Islam adalah pernikahan, yaitu akad yang sangat kuat atau mitssaqan ghalidzan untuk mentaati perintah Allah dan melaksanakannya merupakan ibadah."

Makna tersebut diatas memberikan gambaran bahwa penikahan/ perkawinan mestilah melalui perikatan (aqad) antara seorang pria yang ingin menikah dan wanita yang juga ingin menikah dalam rangka mencapai tujuan mentaati perintah agama. Hal ini dimaksudkan bahwa pernikahan bukan sekedar aqad biasa, akan tetapi lebih membawa kepada suatu bentuk hubungan rumah tangga yang mampu membawa ketakwaan kepada Yang Maha Kuasa, sehingga kesiapan dari masingmasing pihak juga sangat diperlukan.

\section{Dasar Hukum Pernikahan}

Untuk mengacu perbuatannya, terutama dalam kaitannya pembahasan Fiqh, maka hal yang paling penting berikutnya adalah dasar hukum tersebut, sebab apabila hukum tersebut telah mengatur secara tegas dan jelas, maka hal itu mesti kite pedomani. Mengenai dasar hukum pernikahan tentu kita dapat melihat dari berikut ini:

1. Dalam Al-Qur'an

Beberapa kandungan mengenai pernikahan dalam Firman Allah dalam surat An-Nur ayat 32 sebagai berikut ${ }^{11}$ :

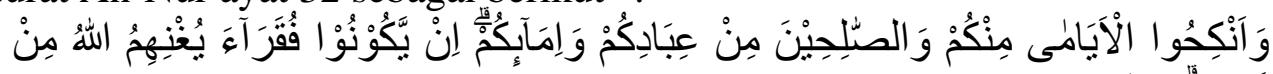

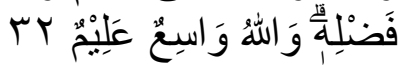

Artinya: Dan nikahkanlah orang-orang yang masih membujang di antara kamu, dan juga orang-orang yang layak (menikah) dari hamba-hamba sahayamu yang laki-laki dan perempuan. Jika mereka miskin, Allah akan

${ }^{9}$ Lihat pada Pasal 1 Undang-undang No. 1 Tahun 1974 Tentang Perkawinan jo Undangundang No. 16 Tahun 2019 tentang Perkawinan .

${ }^{10}$ Lihat pada Kompilasi Hukum Islam pada pasal 2

${ }^{11}$ Departemen Agama RI, Mushaf Al-Quran Terjemah (Jakarta: Pena Pundi Aksara, 2002). Hal. 355 
memberi kemampuan kepada mereka dengan karunia-Nya. Dan Allah Mahaluas (pemberian-Nya), Maha Mengetahui.

Pada ayat lain ditemukan juga pada surat al-Baqarah ayat 221 sebagai berikut $^{12}$ :

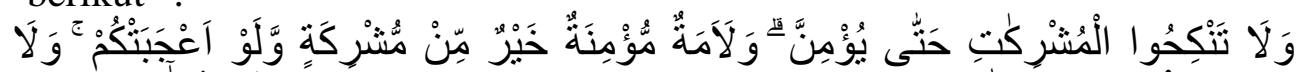

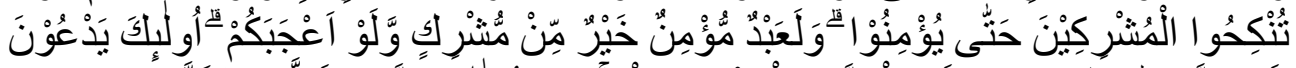

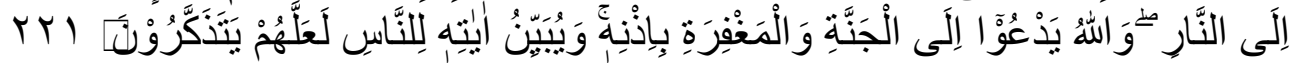
Artinya: Dan janganlah kamu nikahi perempuan musyrik, sebelum mereka beriman. Sungguh, hamba sahaya perempuan yang beriman lebih baik daripada perempuan musyrik meskipun dia menarik hatimu. Dan janganlah kamu nikahkan orang (laki-laki) musyrik (dengan perempuan yang beriman) sebelum mereka beriman. Sungguh, hamba sahaya laki-laki yang beriman lebih baik daripada laki-laki musyrik meskipun dia menarik hatimu. Mereka mengajak ke neraka, sedangkan Allah mengajak ke surga dan ampunan dengan izin-Nya. (Allah) menerangkan ayat-ayat-Nya kepada manusia agar mereka mengambil pelajaran.

2. Dalam Hadits Nabi saw:

Dijelaskan pula dalam Hadits tentang menikah sebagai berikut ${ }^{13}$ :

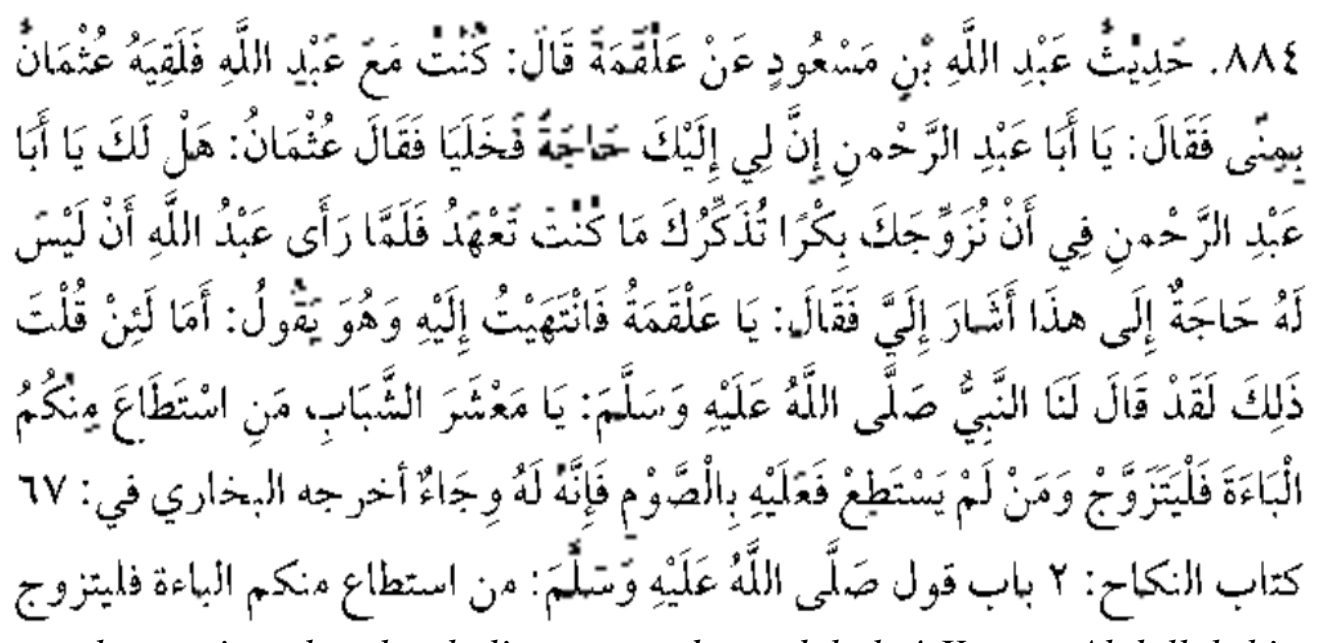
untuk mengingatkan kembali masa mudamu dahulu.' Karena Abdullah bin Mas'ud tidak berhajat kawin, maka dia menunjuk kepadaku dan dipanggil: 'Ya Al-Qamah!' Maka aku datang kepadanya dan dia berkata: 'Jika engkau katakan begitu, maka Nabi i bersabda kepada kami: 'Hai para pemuda, siapa yang sanggup memikul tanggungjawab perkawinan, maka hendaklah kawin, dan siapa yang tidak sanggup, hendaknya berpuasa (menahan diri), karena itu lebih mampu menahan syahwat baginya."' (Dikeluarkan oleh Bukhari pada Kitab ke-68, Kitab Nikah bab ke-2, bab sabda Nabi, barang siapa diantara kalian yang mampu untuk menikah, maka menikahlah)

${ }^{12}$ Ibid, Hal. 36

${ }^{13}$ Muhammad Fu'ad Abdul Baqi, Shahih Bukhari Muslim, trans. oleh Muhammad Ahsan Bin Usman (Jakarta: Elex M edia Komputindo, 2017). Hal. 496 
Pembahasan dasar hukum tentang menikah cukup banyak ditemukan, namun perlu dibatasi pada kaitannya dengan permasalahan perkawinan, sehingga nanti arahan terkait dengan Nikah beda agama akan semakin jelas dan terarah serta mudah dipahami.

\section{E. Tinjauan Umun tentang Nikah Beda Agama}

Nikah beda agama banyak kita jumpai pemahamannya didalam buku dan jurnal yang terkait dalam hal tersebut, sehingga sebelum memformulasikan kedalam bentuk fiqh terutama pada Fiqh kontemporer. Perlunya kita memetakan apa dan bagaimana yang dengan hal Nikah beda agama?

Nikah beda agama secara umum didefenisikan sebagai sebuah ikatan pernikahan yang dilaksanakan seorang laki-laki dan seorang wanita/perempuan yang secara keyakinan memiliki perbedaan, namun atas dasar cinta yang terdapat oleh kedua pasangan tersebut, sehingga mereka sepakat untuk bersama menjalin bahtera rumah tangga ${ }^{14}$. Pelaksanaan perkawinan seperti ini banyak terjadi khususnya di Indonesia terutama bagi beberapa publik figur yang banyak kita lihat diberbagai media.

Pada beberapa defenisi lainya yang dikutip dalam jurnal bahwa dinyatakan Rusli dan juga R. Tama bahwa perkawinan antar-agama yakni berupa perjanjian yang terikat secara lahir batin antara seorang laki-laki yang berkeiginan membangun rumah tangga dan seorang perempuan dikarenakan perbedaan keyakinan masing-masing sehingga terhapusnya aturan pernikahan pada ajaran agama yang dianutnya serta diikuti persyaratan yang dimiliki pada kedua agama tersebut dengan tujuan membangun keluarga harmonis dengan landasan yakin akan Keesaan Tuhan yang dipelopori atas dasar saling cinta ${ }^{15}$. Defenisi diatas tentunya tidak jauh berbeda dengan defenisi sebelumnya, dikarenakan perbedaan agama serta rasa cinta yang ingin mereka membentuk rumah tangga.

Kalau dilihat secara undang-undang perkawinan, maka tidak kita temukan adanya unsur pasal yang memuat tentang pembolehan perkawinan antar agama, dapat dilihat terdapat dalampasal 2 UU Nomor 1 Tahun 1974 tentang perkawinan disebutkan suatu perkawinan dapat dikatakan perkawinan yang sah, jika perkawinan itu dilakukan menurut hukum masing-masing agama dan kepercayaannya itu. ${ }^{16}$ Makna tersebut demikian jelas memberikan arahan hanya pada kepercayaan masing-masing. Oleh karena itu akibat dari ketidaksesuaian aturan tersebut mengakibatkan banyak yang melakukan jalan penyelesaian lain demi melaksanakan pernikahan dengan pasangan yang berbeda agama. Langkah penyelesaian lain tersebut diambil sebagai berikut:

1. Tidak mengindahkan dalam Hukum Nasional dengang membuat atau melangsungkan pernikahan di luar negeri yang melegalkan hal tersebut dan melanjutkan perkawinan tadi yang dilakukan menurut adat masing-masing.

\footnotetext{
${ }^{14}$ Islamiyati, "Analisis Yuridis Nikah Beda Agama Menurut Hukum Islam Di Indonesia," Masalah-Masalah Hukum 16, no. 2 (2016). Hal. 243

15 Zainal Arifin, "Perkawinan Beda Agama," JURNAL LENTERA: Kajian Keagamaan, Keilmuan dan Teknologi 18, no. 1 (2019): 143-58. Hal. 144

${ }^{16}$ Lihat pada Pasal 1 Undang-undang No. 1 Tahun 1974 Tentang Perkawinan
} 
2. Tidak Mengindahkan ketentuan Agama masing-masing misalnya; melangsungkan pernikahan lebih dari 1 kali dan melakukan perubahan/perpindahan keyakinan, sementara diketahui bahwa saat perkawinan berlangsung, kemudian baru kembali pada keyakinan awal setelah perkawinan selesai dilangsungkan. ${ }^{17}$

Terlepas dari itu semua, segala peraturan dalam sistem hukum nasional yang ada baik dalam Perundang-undangan Nomor 1 Tahun 1974 tentang perkawinan dan juga dapat ditemukan dalam KHI tidak mengatur tentang hal tersebut.

Dalam Firman Allah telah dijelaskan tentang kebolehan menikahi wanita non muslim Ahli kitab. Tentunya memahami dan memaknai ahli kitab disini butuh penelusuran yang mendalam tentang apa dan siapa yang termasuk Ahlul kitab yang disebutkan dalam Firman Allah surat Al-Maidah: $5^{18}$.

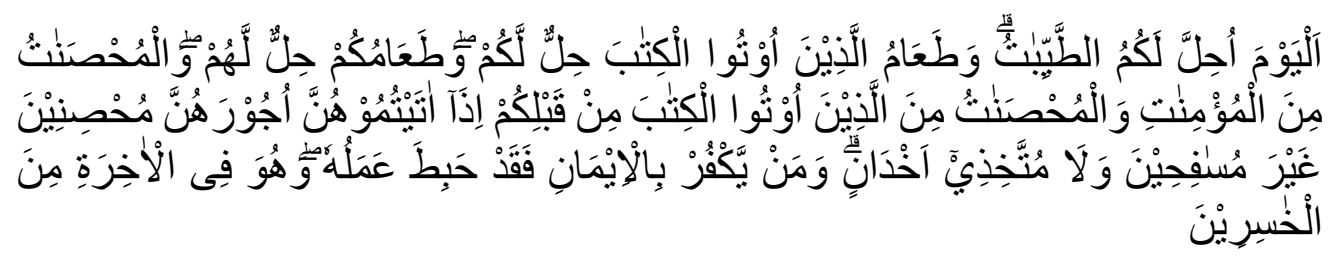

"Pada hari ini dihalalkan bagimu segala yang baik-baik. Makanan (sembelihan) Ahli Kitab itu halal bagimu, dan makananmu halal bagi mereka. Dan (dihalalkan bagimu menikahi) perempuan-perempuan yang menjaga kehormatan di antara perempuan-perempuan yang beriman dan perempuan-perempuan yang menjaga kehormatan di antara orang-orang yang diberi kitab sebelum kamu, apabila kamu membayar maskawin mereka untuk menikahinya, tidak dengan maksud berzina dan bukan untuk menjadikan perempuan piaraan. Barangsiapa kafir setelah beriman, maka sungguh, sia-sia amal mereka, dan di akhirat dia termasuk orang-orang yang rugi.

Pada ayat diatas dinyatakan bahwa tentang membolehkan mengawini perempuan dari kalangan Ahlul kitab, pada kebanyakan ulama tafsir menjelaskan bahwa Ahlul kitab disini merupakan mereka dari yahudi dan nasrani ${ }^{19}$. Dalam sejarah yang diterima bahwa Nabi pernah menikahi wanita dari keturuanYahudi dari suku Quraidlah dan Musthalik, dan seroang wanita dari gubernur romawi mesri bernama Maria al-Qibtiyah ${ }^{20}$. Praktek pernikahan ini pula diikuti oleh sebagian sahabat nabi juga diikuti oleh tabi' in yang melakukan pernikahan laki-laki muslim dan wanita diluar Islam. ${ }^{21}$

${ }^{17}$ Islamiyati, “Analisis Yuridis Nikah Beda Agama Menurut Hukum Islam Di Indonesia." Hal. 244

${ }^{18}$ Kementerian Agama RI, Mushaf Al Quran Terjemah, Op.Cit Hal. 108

${ }^{19}$ Sudarto, Masailul Fiqhiyah al-Haditsah, I (Yogyakarta: Qiara Media, 2019). Hal. 29

${ }^{20}$ Dalam literatur yang didapati bahwa para perempuan ini keturunan yahudi ini ada yang menyatakan belum masuk islam sebelumnya dan juga ada yang mengatakan sudah masuk Islam sebelumnya.

${ }^{21}$ Pernah didapati bahwa para sahabat telah menikahi wanita diluar Islam termasuk : Utsman bin Affan, Sa'ad bin Abi Waqash, Thalhah bin Zubair, Ibn Abbas dan Huzaifah. Sedaangkan Tabi'in yang pernah melakukan pernikahan diluar Islam termasuk Sa'id bin al-Musayyab, Said bin Zubair, 
Namun perlu kita ketahui terlebih dahulu bahwa makna ahlul kitab bentuk istilah yang diberikan kepada orang yang menganut kepercayaan kepada satu keyakinan yang memiliki kitab suci. Kitab suci tersebut dijadikan sebagai pedoman mereka yang berasal dari pencipta. Jika ditilik dari istilah Agama maka ditujukan kepada suatu kelompok pemeluk agama selain islam yang memiliki kitab suci berasal dari wahyu Allah SWT. kepada Nabi Allah dan Rasul Allah dalam gambaran umum. ${ }^{22}$

Meskipun diatas kita melihat contoh yang jalankan oleh para sahabat dan tabi' in, namun yang perlu diperhatikan ialah mesti berhati-hati dalam mencari dan melaksanakan perkawinan beda agama serta keyakinan. Jangan sampai menikahi perempuan yang berbeda agama tersebut hanya karena nafsu belaka yang dilihat berdasarkan kecantikan dan kesenangan lainnya.

Sebelum menjelaskan hukum dari menikah dengan perempuan Ahli kitab, tentunya didefenisikan dulu tentang hal yang menjadi karakteristik ahli kitab dalam pandangan ulama. Sebagaimana dijelaskan sebelumnya bahwa ahli kitab pada umumnya hanya berlaku bagi kelompok yahudi dan nasrani dari bani israel. Hanya saja dalam literatur yang ditemukan bahwa masih terdapat perbedaan pendapat selain dari dua kelompok tersebut diatas, misalnya majusi dan pemeluk lainnya. Pendapat pertama dikemukakan oleh Imam Asy-Syafi'i (W. 204 H) menjelaskan dalam kitab yang ditulisnya al-Umm, telah mendapatkan menerima riwayat yang dinyatakan bahwa Atha' (tabi'in) berkata: "Orang Kristen Arab bukan termasuk ahli kitab. Kaum yang disebut ahli kitab adalah kaum Israel (Bani Israel), yakni orang-orang yang diturunkan kepada mereka kitab Taurat dan Injill”. Adapun orang lain (selain dari Bani israel) yang memeluk agama Yahudi dan Nasrani, mereka bukan termasuk golongan ahli kitab. Definisi ini didukung oleh ayat al-Qur'an yang menyebutkan, bahwa Nabi Isa adalah Rasul khusus untuk Bani Israel (as \}-Shaffat (61): 6). ${ }^{23}$ Dengan kata lain bahwa yang dikatakan Asy-Syafi'i memaknai ahlul kitab sebagai kelompok suatu agama, bukan sebagai suatu kelompok agama yang dibawa oleh Nabi Musa dan Nabi Isa.

Pendapat yang disampaikan imam ath-Thabari, ahli kitab yang dimaksudkan adalah mereka yang beragama Yahudi dan beragama Nasrani dari keturunan manapun diantara mereka, baik dari bangsa Israel sendiri maupun dari kalangan yang bukan dari bangsa Israel. Sedangkan menurut Imam Abu Hanifah dan pendapat ulama Hanafiah dinyatakan bahwa ahli kitab adalah siapapun bagi mereka yang meyakini kepada salah seorang nabi atau kitab suci yang pernah diturunkan Allah SWT, ini tidak terbatas kaum Yahudi dan Nasrani saja. Oleh karen itu bila ada yang yakin akan adanya shuhuf Ibrahim atau dengan kitab Zabur, maka iapun masuk dalam kategori pengertian ahli kitab ini. Selain beberapa argumen yang dikemukakan sebelumnya, bahwa sebagian ulama kategori Salaf menyatakan

Al-Hasan, Mujahid, Thawus dan Ikrimah. Lihat dalam buku Masailul Fiqhiyyah al-Haditsah karangan Sudarto.

${ }^{22}$ Nasrullah, "Ahli Kitab Perdebatan: Kajian Survei Beberapa Literatur Tafsir Al-Qur'an," SYAHADAH 3, no. 2 (2015). Hal. 69

${ }^{23}$ Nasrullah. Hal. 70 
bahwa setiap pengikut yang mendapatkan dan memperoleh kitab suci juga dapat dianggap sebagai ahli kitab, seperti pada orang Majuzi. ${ }^{24}$

Berbeda halnya dengan pendapat ulama kontemporer yang melihat pada perkembang kepercayaan agama saat ini berkembang banyak seperti Majuzi, Sabi'in, Hindu, Budha dan Shinto. Kesemuanya masuk dalam kategori yang disebut dengan ahli kitab. Hal ini sejalan dengan apa yang disampaikan oleh Maulana Muhammad $\mathrm{Ali}^{25}$ yang menegaskan bahwa kaum yang menganut agama Majuzi, Sabiin, Hindu dan Budha dimasukkan dalam kategori ahli kitab. Walaupun keyakinan itu dianggap berkeyakinan dengan arah kesyirikan, namun para pemeluk dari keyakinan tersebut harus diperlakukan seperti ahli kitab. ${ }^{26}$

Berdasarkan pendapat dari maulana muhammad ali ini maka agama yang selain dari kelompok Yahudi dan kelompok Nasrani, bahwa sebuah ajaran yang disertai dengan kitab suci yang sumbernya merupakan pokok yang dibawa oleh nabi dan rasul terdahulu. Pendapat diatas juga sejalan dengan pendapat tokoh lain di Indonesia seperti Nurcholis Madjid yang memaknai Ahli kitab tentang tidak hanya terbatas pada orang-orang dari kalangan Yahudi dan orang-orang dari kalangan Nasrani saja, akan tetapi kepada golongan agama lain dengan tidak menyamakan mereka dengan orang musyrik ${ }^{27}$.

Sedikit berbeda dengan yang disampaikan oleh M. Quraish Shihab, dia memahami defenisi yang menjelaskan tentang Ahlul Kitab dijelaskan hanya bagi mereka yang menganut keyakinanYahudi dan keyakinan Nasrani saja dari kapan, di manapun dan keturunan siapapun. ${ }^{28}$

Dari berbagai macam persepsi dalam kalangan Ulama dan ilmuan yang mempersepsikan tentang Ahli kitab yang terkandung dalam surat al-maidah : 5 tersebut maka dapat digambarkan bahwa pemaknaan tersebut terjadi perbedaan pendapat dalam memahaminya. Namun jika dilihat daripada tingkat kehati-hatian oleh para ulama, khususnya oleh Imam Asy -Syafi'i, maka perlu ditinjau adalah tingkat ahli kitab berdasar kriteria berasal dari golongan Yahudi dan Nasrani kaum bani Israel.

${ }^{24}$ Nasrullah. Hal. 71

25 Maulana Muhammad Ali adalah nama seorang mantan presiden gerakan Ahmadiyah Lahore. lahir pada 1876 di Murar, suatu kampong di kawasan Kapurthala, India.

${ }^{26}$ Nasrullah, "Ahli Kitab Perdebatan: Kajian Survei Beberapa Literatur Tafsir Al-Qur'an.”

${ }^{27}$ Mukhammad Khakim, “Ahl Al-Kitab Menurut Nurcholish Madjid Dan M. Quraish Shihab (Studi Komparatif)" (Universitas Muhammadiyah Surakarta, 2012). Hal 5

${ }^{28}$ Khakim. 


\section{F. Pandangan Pemikiran Mazhab Tentang Nikah Beda Agama}

Setelah membahas sedikit tentang pengertian dari ahli kitab, maka yang menjadi tujuan berikutnya adalah tentang nikah beda agama. Hal ini mengingat beranjak dari pemikiran pemahaman tentang ahli kitab, maka persepsi pemikiran tentang nikah beda agama juga akan memiliki perbedaan. Pandangan para mazhab ini diharapkan menjadi acuan yang bisa dipedomani bagi kalangan masyarakat dan akademisi.

Dalam beberapa pendapat mazhab maka perlu menjadi pandangan bagi kita untuk membahas tentang makalah perkawinan beda agama terutama melakukan pernikahan dengan perempuan yang dari kalangan lain (ahlul kitab), sebagai berikut:

1. Menurut Pendangan Mazhab Hanafi

Dalam mazhab ini dikemukakan bahwa seorang laki-laki yang menikah dengan perempuan Ahli kitab yang disedang berperang melawan kaum muslimin (Dar al-Harb) perbuatan tersebut terlarang. Selain dari kerugian dan bahaya tentunya anak dari hasil perkawinan tersebut cenderung ikut ke agaama ibu ${ }^{29}$.

2. Menurut Pandangan Mazhab Maliki

Mazhab maliki mengajukan 2 pandangan, pertama perbuatan tersebut mengandung sifat makruh, baik wanita tersebut dari kafir zimmi maupun penduduk dar al harb. Kedua, pernyataan dari Al-quran lebih kearah mendiamkan terhadap masalah ahli kitab ini. Disini dapat disimpulkan bahwa sifat mendiamkan tersebut dianggappersetujuan, sehingga status perkawinan dengan ahli kitab boleh-boleh saja tanpa mempertimbangkan dari orang tua juga ahli kitab.

3. Menurut Pandangan Mazhab Syafi'i dan Hambali

Sebagaimana dari Firman Allah surat al-Maidah ayat 5 :

Pada hari ini dihalalkan bagimu segala yang baik-baik. Makanan (sembelihan) Ahli Kitab itu halal bagimu, dan makananmu halal bagi mereka. Dan (dihalalkan bagimu menikahi) perempuan-perempuan yang menjaga kehormatan di antara perempuan-perempuan yang beriman dan perempuan-perempuan yang menjaga kehormatan di antara orang-orang yang diberi kitab sebelum kamu, apabila kamu membayar maskawin mereka untuk menikahinya, tidak dengan maksud berzina dan bukan untuk menjadikan perempuan piaraan. Barangsiapa kafir setelah beriman, maka sungguh, sia-sia amal mereka, dan di akhirat dia termasuk orang-orang yang rugi.

Menurut mazhab syafi'i sebagaimana dijelaskan sebelumnya bahwa Ahli kitab terdiri dari ${ }^{30}$ :

a. Makna Ahlul kitab adalah merekan yang masuk golongan keyakinan Yahudi dan keyakinan Nasrani,

\footnotetext{
${ }^{29}$ Sudarto, Masailul Fiqhiyah al-Haditsah. Hal. 30

${ }^{30}$ Sudarto. Hal. 31
} 
b. Orang majusi tidak dimasukkan ke kategori ahli ktab.

c. orang arab yang masuk kedalam Yahudi dan Nasrani tidak dikategorikan dengan ahli kita dikarenakan asal kepercayaan mereka menyembah berhala dan kepindahannya bukan karena beriman pada taurat dan injil.

Pendapat berikutnya yang dikemukakan oleh Ibn Hazm dalam alMahalla memposisikan ahli kitab dikategorikan dengan golongan Yahudi, nasrani dan Majuzi. Demikian pula dikemukakan dalam Tafsir al-Quran 'Azim dalam kitab tafsir Ibnu Katsir dijelaskan bahwa Abu Sur Ibrahim dan Ibn Khalid al-Kalbi (W. 860 ) merupakan pengikut Imam Syafi'i dan demikian pulan Ahmad bin Hanbal mengatakan bahwa menikmati sembelihan orang majusi dan mengawini wanita mereka diperbolehkan.

Berbeda dalam kelompok yang mengharamkan tentang nikah dengan wanita Ahlul kitab bahwa hal tersebut terdapat dalam Firman Allah SWT surat Al-Baqarah ayat 105, Allah menyatakan:

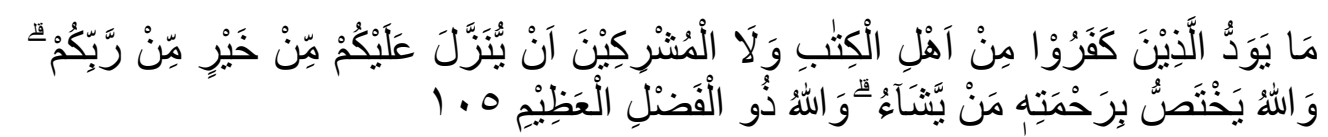

Artinya: Orang-orang yang kafir dari Ahli Kitab dan orang-orang musyrik tidak menginginkan diturunkannya kepadamu suatu kebaikan dari Tuhanmu. Tetapi secara khusus Allah memberikan rahmat-Nya kepada orang yang Dia kehendaki. Dan Allah pemilik karunia yang besar.

Pemaknaan pada ayat diatas lebih menekahnkan pada wajah dilalah nya yang Allah memberikan isyarat bahwa keduanya (ahli kitab dan musyrik) termasuk sama. Artinya sama-sama tidak menyukai Al-Quran diturunkan kepada umat islam. ${ }^{31}$ Oleh karena hal tersebut, maka status hukumnya adalah haram sebagaimana yang dijelaskan pada surat al-Baqarah ayat 221. Dalam ayat lain Allah berfirman dalam Surat Al-Bayyinah ayat 1:

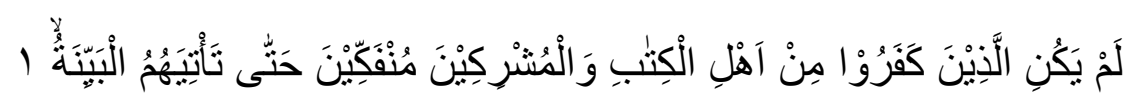

Artinya: "Orang-orang yang kafir dari golongan Ahli Kitab dan orang-orang musyrik tidak akan meninggalkan (agama mereka) sampai datang kepada mereka bukti yang nyata,"

Pada penjelasan ayat diatas menerangkan bahwa tidak adanya perbedaan antara golongan kafir dari mereka yang ahlul kitab dan golongan yang musyrik. Kedua kelompok ini tidak akan menjauhkan kelompok mereka jika mereka mendapatkan kebenaran lain yang lebih nyata. ${ }^{32}$

\section{G. Analisis Fiqh Kontemporer dan Tatanan Hukum Nasional terhadap Nikah Beda Agama}

Setelah memahami dan mendalami pemahaman pada dalil yang berhubungan dengan masalah nikah beda agama tersebut, maka perlu dicermati kembali tentang

${ }^{31}$ Asmuni dan Nispul Khairi, Fiqh kontemporer : Dalam Ragam Aspek Hukum (Medan: Wal Ashri Publishing, 2017). Hal. 87

${ }^{32}$ Asmuni dan Khairi. Hal. 88 
konsekuesi hukum yang diterima ketika melaksanakan perbuatan tersebut. Baik yang melakukan pernikahan antara seorang laki-laki Muslim dengan seorang perempuan Ahli Kitab, maupun seorang Laki-laki muslim dengan seorang perempuan bukan ahli kitab.

Dimulai dari pemahaman tentang perkawinan dari seorangpria berkeyakinan Islam dan seorang wanita dari kalangan Ahlul Kitab menyepakati pada surat almaidah ayat 5. Imam Syafi'i memberikan argumen tentang ahlul kitab yakni bagi orang dari kaum Yahudi dan orang dari kaum Nasrani (Kristen) terutama berasala dari nasabnya bani israil. Karena itu, negara-negara lain yang menganut agama Yahudi dan Kristen tidak termasuk dalam Ahlul kitab. Sementara itu, Abu Hanifah dan mayoritas ahli hukum yang menyatakan, siapa saja yang percaya pada salah satu nabi, atau buku yang diturunkan oleh Allah, maka ia Ahlul kitab.

Pendapat lain yang dipegang oleh sejumlah kecil ulama salaf mengatakan bahwa setiap orang yang memiliki kitab yang dapat dugaan sebagai kitab suci (samawi) juga termasuk dalam pemahaman Ahlul kitab, seperti mereka yang Majusi.

Muhammad Rasyid Ridha (1367 H : 193) diperluas juga olehnya bahwa kaum Majusi, Șabi'in, Hindu, Budha, Khonghucu, Shinto dan keyakinan yang lain masuk dalam golongan ahlul kitab. Pendapatnya bahwa keyakinan tersebut pada mulanya berpaham satu tuhan(monoteisme) dan juga memiliki kitab suci dari ajaran tersebut..

Berdasarkan banyaknya perbedaan tersebut, M. Quraish Shihab mengatakan bahwa ahlul kitab adalah semua penganut Yudaisme dan Kristen (Kristen), kapan saja, di mana saja dan dari keturunan siapa pun. Ini didasarkan pada penggunaan Alquran dengan istilah yang hanya terbatas pada dua kelompok, yaitu Yahudi dan Kristen (Nasrani). ${ }^{33}$

Mereka yang termasuk dalam mendukung adanya larangan menikah dengan perempuan ahlul kitab yakni dari kalangan sahabat nabi Abdullah bin Umar yang mengatakan:

"Saya tidak tahu kemusyrikan yang lebih besar dari kepercayaan seorang wanita yang mengatakan bahwa Tuhannya adalah Yesus atau salah satu hamba Tuhan". (Imad al-Din Abi al-Fida' Ismail bin Umar bin Katsir alQurasyiy al-Dimasyqiy, 1421 H/2000 M: 357

Hampir seluruh hampir seluruh sahabat nabi, tabi'in, ulama-ulama masa awal dan kontemporer tidak setuju dengan Abdullah bin Umar. Ini bisa dipahami, mengingat latar belakang Abdullah bin Umar dikenal sangat berhati-hati, serta berusaha sebaik-baiknya meniru Nabi Muhammad. dalam semua sikap dan tindakannya. Inilah yang membuatnya begitu ketat dalam pendapatnya tentang pernikahan pria Muslim dengan wanita yang ahlul kitab tersebut.

Mahmud Syaltut menulis dalam koleksi fatwanya, bahwa tujuan utama dari memungkinkan pernikahan seorang pria Muslim dengan seorang wanita ahlulkitab adalah bahwa dengan pernikahan semacam itu terjadi semacam hubungan cinta dan kasih sayang, sehingga mengikis dari benak istrinya dan Perasaan tidak simpatik

${ }^{33}$ Abdul Jalil, "Pernikahan Beda Agama dalam Perspektif Hukum Islam dan Hukum Positif di Indonesia," Andragogi: Jurnal Diklat Teknis Pendidikan dan Keagamaan 6, no. 2 (2018): 46-69. Hal. 57 
terhadap Islam dengan tingkah laku yang baik dari suami Muslim dari agama yang berbeda itu, sehingga tercermin keindahan amaliah dan keutamaan Islam. ${ }^{34}$

Dalam catatan lain ditemui bahwa pernah terjadi kasus pernikahan yang terjadi terkait dengan pernikahan yang akan tercatat atas nama Ani Vonny Gani P dari Islam dengan laki-laki bernama Petrus Hendrik Nelwan dari keyakinan Kristen. berdasarkan Putusan MA No 1400 K/Pdt/1986 Catatan Sipil diperkenankan untuk melanjutkan perkawinan beda agama yang mereka lakukan. ${ }^{35}$

Majelis Ulama Indonesia (MUI) melarang pernikahan antara seorang pria dari Islam kemudian dengan seorang wanita dari kalangan bukan Islam yang Ahlul kitab, berdasarkan pertimbangan manfaat agama dan keharmonisan hubungan rumah tangga yang tidak dapat dengan mudah dibangun jika pasangan menikah tidak setuju dengan ide-ide mereka, pandangan hidup atau agama (Fatwa Majelis Ulama Indonesia 1426 H/2005 M). ${ }^{36}$

Jika dilihat secara konteks KHI yang dikeluarkan pada Instruksi Presiden Nomor 1 Tahun 1991 yang sampai hari ini menjadi pegangan bagi hakim-hakim yang lingkupnya di Pengadilan Agama untuk memutuskan dan menetapkan dasar hukum yang terkait. Mengenai hal ini KHI jika dilihat pada pasal 40 ayat (c) menjelaskan tentang pelarangan seorang laki-laki dengan keyakinan Islam untuk melangsungkan pernikahan dengan perempuan yang berkeyakinan bukan islam, selanjutnya ditambah lagi pada pasal 44 menjelaskan tentang pelarangan wanita bergamama islam dengan laki-laki yang non muslim ${ }^{37}$. Jelaslah bahwa dalam Kompilasi Hukum Islam memberikan penegasan bahwa segala bentuk pernikahan berlangsung pada pasangan yang secara keyakinan berbeda, maka tidak dibenarkan untuk dilakukan oleh kaum muslimin di Indonesia.

Mengenai pelarangan ini juga, Ibnu umar menemukan masalah dalam bentuk perwalian, para ulama sepakat bahwa syarat seorang wali haruslah beragama islam. Disamping itu pula terkait dengan terhalangnya memperoleh warisan.

Kesimpulan yang diambil dalam problematika diatas, melihat kondisi dan kultur khususnya pada masyarakat di Indonesia akan tetapi secara moral jika melihat kultur budaya serta agama di Indonesia pernikahan beda agama sedikit banyak tetap akan menjadi polemik dikalangan masyarakat dan ikut menciptakan gesekan social dimasyarakat karena pada hakekatnya pernikahan dianggap suatu hal yang sakral dan suci yang dalam pelaksanaan dan syarat pernikahanya wajib mengikuti ketentuan agama.

Melihat dari pandangan pemikiran diatas, maka senada dengan beberapa kaidah fiqh yang dapat disandingkan:

$$
\text { درء المفاسد مقدم على جلب المصالح }
$$

Menolak Mafsadah (Kemudharatan) didahulukan dari maslahah.

${ }^{34}$ Abdul Jalil. Hal. 59

35 Kompasiana.com, "Pernikahan Beda Agama dalam Hukum Positif Indonesia (Suatu Tinjaun Singkat)," KOMPASIANA, t.t., diakses 13 Maret 2020.

${ }^{36}$ Abdul Jalil, "Pernikahan Beda Agama dalam Perspektif Hukum Islam dan Hukum Positif di Indonesia." Hal. 60

${ }^{37}$ Ibid, Hal. 62 
Melihat dari kaidah diatas tentu dapat menjadi pedoman dalam penetapan ini, sehingga mencegah mudharat menjadi hal yang penting sebelum terjadi hal tidak diinginkan. Terlebih lagi penikahan bentuknya akad yang kuat, dalam rangka tujuan membina keluarga yang harmonis.

\section{H. Kesimpulan}

Berdasarkan pada kondisi diatas, maka dapat ditarik kesimpulan bahwa menikahi perempuan musyrik jelas perbuatan nya terlarang dengan hukumnya haram. Sedangkan menikah perempuan Ahli kitab meski banyak terjadi perbedaan pendapat namun tentunya harus dilihat dari aspek maslahat yang paling utama. Oleh karena itu dengan melihat kondisi tersebut status hukumnya haram. Hal ini didukung dengan Fatwa MUI serta tidak terdapatnya aturan yang mengatur tentang nikah beda agama dalam Kompilasi Hukum Islam dan UU No. 1 Tahun 1974 tentang perkawinan.

\section{DAFTAR PUSTAKA}

kumparan. "5 Artis Yang Menikah Beda Agama," t.t. Diakses 8 Maret 2020.

Abdul Baqi, Muhammad Fu'ad. Shahih Bukhari Muslim. Diterjemahkan oleh Muhammad Ahsan Bin Usman. Jakarta: Elex M edia Komputindo, 2017.

Arifin, Zainal. "Perkawinan Beda Agama." JURNAL LENTERA: Kajian Keagamaan, Keilmuan dan Teknologi 18, no. 1 (2019): 143-58.

Asmuni, dan Nispul Khairi. Fiqh kontemporer: Dalam Ragam Aspek Hukum. Medan: Wal Ashri Publishing, 2017.

Atabik, Ahmad, dan Khoridatul Mudhiiah. "Pernikahan dan Hikmahnya Perspektif Hukum Islam.” YUDISIA: Jurnal Pemikiran Hukum Dan Hukum Islam 5, no. 2 (2016).

Gulo, W. Metodologi Penelitian. Jakarta: Gramedia Widiasarana Indonesia, 2002.

Ibnu Abdul Aziz Al Malibari, Zainuddin. Fathul Muin Jilid 3. Diterjemahkan oleh Abul Hiyadh. I. Surabaya: Al-Hidayah, 1993.

Islamiyati. "Analisis Yuridis Nikah Beda Agama Menurut Hukum Islam Di Indonesia." Masalah-Masalah Hukum 16, no. 2 (2016).

Jalil, Abdul. "Pernikahan Beda Agama dalam Perspektif Hukum Islam dan Hukum Positif di Indonesia." Andragogi: Jurnal Diklat Teknis Pendidikan dan Keagamaan 6, no. 2 (2018): 46-69.

Jamaluddin, dan Nanda Amalia. Buku Ajar Hukum Perkawinan. Unimllal Press, 2016.

Khakim, Mukhammad. "Ahl Al-Kitab Menurut Nurcholish Madjid Dan M. Quraish Shihab (Studi Komparatif).” Universitas Muhammadiyah Surakarta, 2012.

Kompasiana.com. "Pernikahan Beda Agama dalam Hukum Positif Indonesia (Suatu Tinjaun Singkat).” KOMPASIANA, t.t. Diakses 13 Maret 2020.

Nasrullah. "Ahli Kitab Perdebatan: Kajian Survei Beberapa Literatur Tafsir AlQur'an." SYAHADAH 3, no. 2 (2015). 
RI, Departemen Agama. Mushaf Al-Quran Terjemah. Jakarta: Pena Pundi Aksara, 2002.

Sudarto. Masailul Fiqhiyah al-Haditsah. I. Yogyakarta: Qiara Media, 2019.

Yusuf, A. Muri. Metode Penelitian: Kuantitatif, Kualitatif, dan Penelitian Gabungan. Jakarta: Kencana, 2015. 